Environmental Science \& Technology

April 2018, Volume 52, Issue 9, Pages 5277-5286

http://dx.doi.org/10.1021/acs.est.8b00168

http://archimer.ifremer.fr/doc/00435/54684/

(c) 2018 American Chemical Society

\title{
Microplastics Affect Energy Balance and Gametogenesis in the Pearl Oyster Pinctada margaritifera
}

\author{
Gardon Tony ${ }^{1}$, Reisser Celine ${ }^{1}$, Soyez Claude ${ }^{1}$, Quillien Virgile ${ }^{1}$, Le Moullac Gilles ${ }^{1}$ \\ ${ }^{1}$ Ifremer, UMR Ecosystèmes Insulaires Océaniens (EIO), UMR 241 UPF/ILM/IRD/lfremer, Centre du \\ Pacifique, BP 49, 98719, Taravao, French Polynesia
}

\begin{abstract}
:
Plastic pollution in the environment is increasing at global scale. Microplastics (MP) are derived from degradation of larger plastic items or directly produced in microparticles form $(<5 \mathrm{~mm})$. Plastics, widely used in structures and equipments of pearl farming, are a source of pollution to the detriment of the lagoon ecosystem. In order to evaluate the impact of MP on the physiology of Pinctada margaritifera, a species of ecological and commercial interests, adult oysters were exposed to polystyrene microbeads (micro-PS of 6 and $10 \mu \mathrm{m}$ ) for 2 months. Three concentrations were tested: $0.25,2.5,25 \mu \mathrm{g} \mathrm{L}-1$ and a control. Ingestion and respiration rate and assimilation efficiency were monitored on a metabolic measurement system to determine the individual energy balance (Scope For Growth, SFG). Effects on reproduction were also assessed. The assimilation efficiency decreased significantly according to microPS concentration. The SFG was significantly impacted by a dose-dependent decrease from $0.25 \mu \mathrm{g} \mathrm{L-1}$ $(p<0.0001)$. A negative SFG was measured in oysters exposed to $25 \mu \mathrm{g} \mathrm{L}-1$. Gonads may have provided the missing energy to maintain animals' metabolism through the production of metabolites derived from germ cells phagocytosis. This study shows that micro-PS significantly impact the assimilation efficiency and more broadly the energy balance of $P$. margaritifera, with negative repercussions on reproduction.
\end{abstract}


26

27

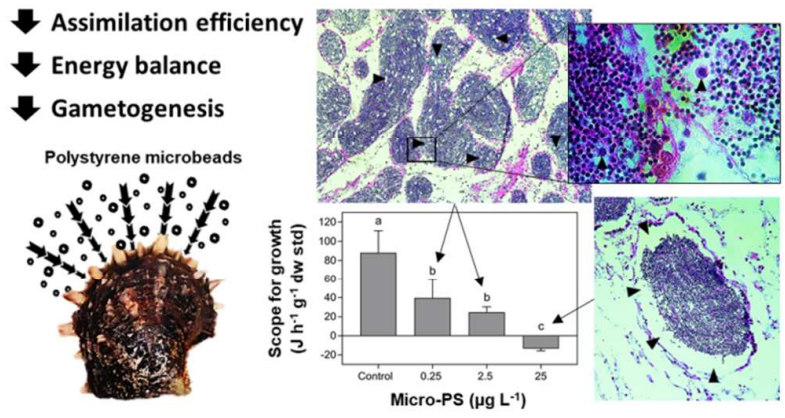

\section{INTRODUCTION}

Through their immense potential and countless properties, plastics hold a highly prevalent place in contemporary society. Plastic production increased dramatically worldwide over the last 60 years, increasing from 0.5 million tons per year in 1960 to 322 million tons in $2015 .{ }^{1}$ About $5-10 \%$ of this annual plastic production is rejected in the marine environment, ${ }^{2}$ and their degradation can take several hundred years. ${ }^{3}$ Microplastics (MP, plastic particles $<5$ $\mathrm{mm}){ }^{4}$ can be defined as primary MP or secondary MP, depending on their origins. ${ }^{3}$ The majority of MP found in the oceans are secondary MP produced through the fragmentation of larger items under the action of biotic (i.e., biodegradation) and abiotic factors (e.g., photolysis, hydrolysis, thermooxidative and thermal degradation). ${ }^{5}$ By opposition, primary MP are directly released into the environment as microparticles, and come from industrial sources (e.g., toothpaste, manufactured products from cosmetic industry, or macroplastic manufacturing base). ${ }^{5}$

Given their ubiquitous nature and small dimensions, MP are likely to be ingested by many organisms ${ }^{3,6-9}$ inducing various physical and biological effects, ${ }^{10}$ especially in several filterfeeding species such as bivalves, ${ }^{11-14}$ sea cucumbers, ${ }^{15}$ lugworm, ${ }^{16,17}$ and zooplankton. ${ }^{18-21}$ MP ingestion substantially impacts key physiological functions such as nutrition, ${ }^{18,22,23}$ 
45

assimilation efficiency, ${ }^{24}$ respiration, ${ }^{25}$ reproduction, ${ }^{14,26}$ growth, ${ }^{23}$ and survival. ${ }^{25,27}$ For example, in a chronic 4-weeks exposure to microfibers (1-5 mm in length, $1 \%$ plastic diet), the crab Carcinus maenas showed reduced food consumption (from 0.33 to $0.03 \mathrm{~g} \mathrm{~d}^{-1}$ ) and a significant reduction in energy available for growth (scope for growth) from 0.59 to $-0.31 \mathrm{~kJ}$ crab d $\mathrm{d}^{-1} \cdot{ }^{23}$ In addition to physical effects (e.g., induction of a false sense of satiety, alteration of feeding capacity, digestive tract obstruction), ${ }^{18,19,22}$ ingested MP can also result in reserves depletion, ${ }^{17}$ hepatic stress, ${ }^{28}$ and reduced fecundity. ${ }^{19,20}$ At the cellular and molecular level, MP can be translocated in the circulatory system, ${ }^{11}$ induce oxidative stress $^{21}$ neurotoxic effects, genotoxicity and alter immunological responses ${ }^{13}$ after desorption of persistent organic pollutants. $^{29,30}$

While the quantification of MP in seawater is very difficult, their potential ingestion by species of economical and commercial interest is a cause for concern. This is especially true for bivalves, since many are world-wide exploited species, and are suspension filter-feeding organisms, directly exposed to MP present in the water column. ${ }^{12}$ A recent study examined the effects of MP on the Pacific oyster, Crassostrea gigas, by exposing the animals to fluorescent polystyrene microbeads (micro-PS of 2 and $6 \mu \mathrm{m}$ diameter, $23 \mu \mathrm{g} \mathrm{L}^{-1}$ ) over a 2months period. ${ }^{14}$ This study revealed a significant impact of MP on the reproduction of exposed oysters through a marked decrease in fertility $(-41 \%)$, oocyte number $(-38 \%)$ and size $(-5 \%)$; as well as a decline in spermatozoa mobility (-23\%). Furthermore, larvae produced by exposed oysters showed a delayed growth of about $20 \% .{ }^{14}$ This recent work highlights the reprotoxic effects of MP on C. gigas, and a transgenerational effect by altering the development of the next generation of individuals produced by breeders exposed to MP. The dose tested in this study (i.e., $23 \mu \mathrm{g} \mathrm{L}{ }^{-1}$ ) referring to a mass concentration in the range of the highest estimated field concentration $>333 \mu \mathrm{m}$, from manta trawl sampling in North Western Mediterranean Sea. ${ }^{31}$ Although this dose is likely to be higher than the mean concentrations 
encountered in the natural environment (even if environmental doses are unknown at this range of sizes, ${ }^{32}$ i.e. 2 and $6 \mu \mathrm{m}$ ), the long-term consequences of MP are of concern for oyster related economy.

In French Polynesia (FP), pearl farming occupies an important part in the economical, environmental and social landscape of the territory. The pearl oyster, Pinctada margaritifera, is a tropical species of economical interest for the trade of pearls and mother-of-pearl. It is also a species of ecological interest and serves as a biological model for lagoon ecosystems and environmental survey. Indeed, as most of filter-feeding organisms, oyster plays a predominant role in the benthic and pelagic ecosystems junction by exercising a local control on nutrient cycle and primary productivity. ${ }^{33}$ In comparison with other bivalves, $P$. margaritifera has particularly high filtration rates, and can filter up to $26 \mathrm{~L}$ seawater per hour. ${ }^{34}$ It can feed on a wide range of particle sizes ( 2 to $\left.200 \mu \mathrm{m}\right)$, with an optimal retention rate for particles of $5 \mu \mathrm{m}$ and over. ${ }^{34}$ As many filter-feeding species, the pearl oyster removes particulate matter from water column and transfers them to the sediment as biodeposits. Biodeposition is probably a key mechanism by which neutral buoyancy MPs are transported from water column to sediments. ${ }^{35}$ The pearl oyster could therefore affect MP distribution and concentration, which could alter algal communities and benthic macrofauna, ${ }^{36}$ and thus disrupt the biological balance of lagoon ecosystem.

In recent years, the economic decline of pearl farming led to concessions closures, which are sometimes abandoned with all the remaining structures still in the lagoon. In addition, operational concessions are also leaving their inoperative farming structures in the lagoon, by drowning them, ${ }^{37}$ generating its own risk regarding the impact of MP on the local environment and economy. The inventory carried out by Andréfouët et al. in the pearl lagoon of Ahe atoll (FP) revealed large quantities of synthetic ropes, collectors, fencing, buoys and nylon cords. ${ }^{37}$ These breeding structures, essentially made of plastics, could represent a 
considerable source of MP, and more so considering the semi-closed environment of some cultured lagoons which could favour MP concentration. ${ }^{37}$ The related proximity to the South Pacific subtropical gyre may also contribute to MP contamination in French Polynesia waters. ${ }^{38}$ A recent study has estimated a mean MP concentration of 0.74 pieces $\mathrm{m}^{-2}$ surface area in Moorea (FP) water column. ${ }^{39}$ Although MP contamination of Polynesian waters also likely comes from open sea and local industries, pearl farming might be generating its own risk regarding the impact of MP on the local environment and economy.

This study investigated the impacts of polystyrene microbeads (micro-PS 6 and $10 \mu \mathrm{m}$ ) on P. margaritifera by evaluating their effects on the individual energy budget, which gathers the ingestion, respiration and assimilation efficiency responses. Effects on reproduction were also discussed by the analysis of individual reproductive effort and the gametogenesis condition. Three main questions were posed: (1) what is the effect of microplastics on the physiology of the pearl oyster? (2) How is the energy managed and allocated between the basal metabolic rate and the reproduction? (3) Are the oyster's responses dose-dependent, and is there a threshold? To meet these objectives and target a response window with dose-effect relationship, a 2-month exposure of adult oysters to 3 micro-PS doses $\left(0.25,2.5\right.$ and $25 \mu \mathrm{g} \mathrm{L} \mathrm{L}^{-}$

$\left.{ }^{1}\right)$ was performed under controlled conditions. To our knowledge, this is one of the first studies investigating a specific dose-effect of microplastics on the energy available for growth (scope for growth) and reproduction in exposed marine organisms.

\section{MATERIALS AND METHODS}

Experimental animals and acclimation. Pearl oysters were sampled on October 17, 2016 in a pearl farm located in the Arutua atoll $\left(15^{\circ} 14^{\prime} 43^{\prime \prime} \mathrm{S} ; 146^{\circ} 36^{\prime} 43^{\prime \prime} \mathrm{O}\right)$, in the Tuamotu archipelago (French Polynesia, FP). A stock of approximately 350 adult oysters (1-1.5 years old; height, $5.9 \pm 0.41 \mathrm{~cm}$; weight, $25.2 \pm 4.9 \mathrm{~g}$, mean $\pm \mathrm{SD}$ ) were transferred (transfer 
authorization No. 3761 issued by the Ministry of Marine Resources of French Polynesia) to the lagoon of Vairao (Ifremer marine concession No. 8120/MLD: 17²48'26.0"S, $149^{\circ} 18^{\prime} 14.4^{\prime \prime} \mathrm{W}$, Tahiti, FP) on October 19, 2016. Before being packaged and transferred, all oysters were carefully inspected, cleaned and treated with saline water to remove parasites.

Polystyrene microbeads. Polystyrene is one of the most commonly used plastic polymers worldwide, often found in MP sampled in marine ecosystems. ${ }^{3}$ Dependent on the optimum retention rate of pearl oysters, we used unlabeled polystyrene microbeads (micro-PS) with diameters of 6 and $10 \mu \mathrm{m}$, purchased from Polyscience (Polybead ${ }^{\circledR}$, Washington, PA, U.S.). Micro-PS of 6 and $10 \mu \mathrm{m}$ were packaged in aqueous solution (Milli-Q ${ }^{\circledR}$ water) at a concentration of $2.10 \times 10^{8}(2.5 \% \mathrm{w} / \mathrm{v}, 5 \mathrm{~mL})$ and $4.55 \times 10^{7}(2.5 \% \mathrm{w} / \mathrm{v}, 5 \mathrm{~mL})$ particles $\mathrm{mL}^{-1}$ respectively. The two solutions were mixed in order to obtain a stock solution $(10 \mathrm{~mL})$ containing the two microbead diameters at equal weight. Polymer type of virgin micro-PS was confirmed using a Raman micro-spectroscopy analysis (Figure SI.1 in the Supporting Information). A fragment of additive-free reference polystyrene supplied by GoodFellow Cambridge Ltd (Lille, France) was used as spikes for the spectra comparison and measurements were carried out using a LabRAM HR800 Raman micro-spectrometer (Horiba Scientific), equipped with a Horiba Scientific ParticleFinder module for LabSpec6.

In vivo exposure. To assess the dose-effect of MP on the physiology and reproduction of P. margaritifera, oysters were exposed to 3 doses of micro-PS over a 2-month period: 0.25 , 2.5, $25 \mu \mathrm{g} \mathrm{L} \mathrm{L}^{-1}\left(3.2 \times 10^{2}, \times 10^{3}, \times 10^{4}\right.$ particles $\mathrm{L}^{-1}$, respectively $)$ and were compared to a control $\left(0 \mu \mathrm{g} \mathrm{L}^{-1}\right)$ (Figure 1). After acclimation (2 weeks of depuration), oysters were conditioned in 4 experimental 20 -L tanks per treatment ( 6 oysters per tank, i.e. 24 oysters per treatment). The tanks seawater supply (natural seawater pumped from the lagoon) was mechanically filtered on 25 and $5 \mu \mathrm{m}$ sock filters. In each tank, a system of 2 air-lifts connected to the pressurized air circuit maintained the homogeneity of the medium. Micro-PS of 6 and $10 \mu \mathrm{m}$ were 
144 incorporated at equal weights according to the different tested doses (micro-PS ratio 6/10 $\mu \mathrm{m}$ :

145 4.614), and were injected continuously in the experimental design associated with a mixed 146 diet of two microalgae (Tisochrysis lutea, formerly Isochrysis galbana, Tahitian strain: T-Iso, 147 and Chaetoceros gracilis) at a daily ratio equal to 7-8\% dry-weight-algae/dry-weight-oyster. 148 The ration was determined according to the threshold for triggering pseudo-faeces production, 149 so as to avoid an overestimation of ingestion measurements. This resulted in a mean 150 concentration of 35 to 40 cells $\mu \mathrm{L}^{-1}$ in the water surrounding the oysters. The micro151 PS/microalgae mixture was made every 24 hours in four 50-L cylindro-conical tank (1 per treatment). To avoid agglutination, micro-PS particles were preliminary mixed with Tween20 at $10 \%$ of the micro-PS stock solution volume before being supplied to tanks. Tween-20 was also supplied to the control tank at the same rate $(7 \mu \mathrm{L})$ as for the lowest micro-PS concentration (i.e., $0.25 \mu \mathrm{g} \mathrm{L}^{-1}$ ). For each treatment, the microbeads and algae mixture was adjusted to $40 \mathrm{~L}$ with filtered $(25$ and $5 \mu \mathrm{m})$ seawater. The mixture was distributed by a 157 peristaltic pump (16-way head, Ismatec $\left.{ }^{\circledR}\right)$ set at 75 turns $\min ^{-1}$, i.e., $1.5 \mathrm{~L}$ of injected mixture 158 per hour into the seawater supply of each 4 treatments for a total flow of $28 \mathrm{~L} \mathrm{~h}^{-1}$ (i.e., $7 \mathrm{~L} \mathrm{~h}^{-1}$ $159 \operatorname{tank}^{-1}$ ). Oysters were maintained at $28.9 \pm 0.3{ }^{\circ} \mathrm{C}$ under a $12 \mathrm{~h}$ light: $12 \mathrm{~h}$ dark cycle throughout the duration of the exposure. The $\mathrm{pH}$, dissolved oxygen and salinity of the seawater were $8.2,6.6 \pm 0.7 \mathrm{mg} \mathrm{O}_{2} \mathrm{~L}^{-1}$ and $35 \mathrm{psu}$, respectively. In order to avoid contamination of the natural environment with microbeads, discharges were filtered successively on 5 and $1 \mu \mathrm{m}$ sock filters.

166 clearance rate and oxygen consumption. The EMS consisted of five hemispheric open-flow 167 chambers in transparent Altuglas ${ }^{\circledR}$. One oyster was placed in each chamber and the fifth 168 chamber was occupied by an empty oyster shell to be used as control. ${ }^{40}$ Experimental 
169

170

171

172

173

174

175

conditions during in vivo exposure were replicated in the EMS during measurements. For this, the chambers contained water at the same temperature (mean of $28.5 \pm 0.3{ }^{\circ} \mathrm{C}$ ) and concentration of algae as in the treatments tanks. Flow rates in the chambers were constant at $12 \mathrm{~L} \mathrm{~h}^{-1}$. Each chamber was equipped with a two-way electromagnetic valve activated by an automaton. When the valve of one measuring chamber was opened, the released water was analysed for 3 min using a fluorometer (10-AU ${ }^{\mathrm{TM}}$, Turner Designs, Sunnyvale, CA) to measure microalgae fluorescence, then an oximeter (OXI 538/CellOX ${ }^{\circledR} 325$, WTW, Weilheim, Germany) to measure dissolved oxygen. Data on clearance rate and oxygen consumption were stored on a computer with an acquisition software (computer programming by National Instruments ${ }^{\mathrm{TM}}$ ) and each cycle was completed within $3 \mathrm{~min}$ and another cycle started in the control chamber for 3 min (sequence: chamber 1, control, chamber 2, control, chamber 3, etc.). Oysters remained in the chambers for at least $48 \mathrm{~h}$; measurements of each oyster were taken every 24 min until 120 measurements of clearance rate and oxygen consumption had been recorded. ${ }^{40}$ A total of 32 oysters were individually monitored in the EMS (8 oysters per treatment). Assimilation efficiency was measured after collecting biodeposits (i.e., faeces) in each hemispheric chamber and $50 \mathrm{~mL}$ of microalgae mixture administered during ecophysiological measurements.

Ingestion Rate (IR). IR is an indicator of feeding activity, and is defined as the quantity of microalgae cleared per unit of time. IR was estimated using fluorescence measurements and calculated as: IR $=\mathrm{V} \times\left(\mathrm{C}_{1}-\mathrm{C}_{2}\right)$, where $\mathrm{C}_{1}$ is the fluorescence level of the control chamber, $\mathrm{C}_{2}$ is the fluorescence of the experimental chamber containing one oyster, and $\mathrm{V}$ is the constant water flow rate $\left(12 \mathrm{~L} \mathrm{~h}^{-1}\right) .^{40}$

Oxygen Consumption rate (OC). OC was measured $\left(\mathrm{mg} \mathrm{O}_{2} \mathrm{~h}^{-1}\right)$ by calculating the differences in $\mathrm{OC}$ between the control and experimental chambers: $\mathrm{OC}=\mathrm{V} \times\left(\mathrm{O}_{1}-\mathrm{O}_{2}\right)$, 
193

194

195

196

197

198

199

200

201

202

203

204

205

206

207

208

209

210

211

212

213

214

215

216

217

where $\mathrm{O}_{1}$ is the oxygen level in the control chamber, $\mathrm{O}_{2}$ is the oxygen level in the experimental chamber, and $\mathrm{V}$ is the water flow rate. ${ }^{40}$

Ingestion and oxygen consumption rates were estimated and an average calculated for each oyster, taking into account all values recorded after the measurements to stabilize. To compare IR and OC, it was necessary to correct for differences in specimen weight. Values of the ecophysiological activities were converted to a standard animal basis ( $1 \mathrm{~g}$, dry weight), using the formula: $Y_{s}=\left(W_{s} / W e\right)^{b} \times Y e$, where $Y_{s}$ is the physiological activity of a standard oyster, $W s$ is the dry weight of a standard oyster $(1 \mathrm{~g}), W e$ is the dry weight of the specimen, $Y e$ is the measured physiological activity, and $b$ is the allometric coefficient of a given activity. The average $b$ allometric coefficients were 0.66 for ingestion rate and 0.75 for oxygen consumption rate. ${ }^{41}$

Assimilation Efficiency (AE). AE of organic matter was assessed by analysing microalgae and faeces according to the method of Conover (1966) and described by ChávezVillalba et al. (2013). ${ }^{40}$ Biodeposits of each individual were treated individually by filtration on a GF/C filter $\left(1.2 \mu \mathrm{m}\right.$ of porosity, $\varnothing 47 \mathrm{~mm}$, Whatman $\left.{ }^{\circledR}\right)$ previously burned at $450{ }^{\circ} \mathrm{C}$ and weighed. Filters were then dried at $60{ }^{\circ} \mathrm{C}$ for $24 \mathrm{~h}$ in order to obtain the dry weight of biodeposits (DW) and then burned (Thermolyne ${ }^{\mathrm{TM}}$ Type $47900 \& 48000$ Furnaces, Thermo Scientific ${ }^{\mathrm{TM}}$ ) at $450{ }^{\circ} \mathrm{C}$ for $4 \mathrm{~h}$ to obtain the weight of the mineral matter $\left(\mathrm{W}_{\mathrm{MM}}\right)$. The weight of organic matter $\left(\mathrm{W}_{\mathrm{OM}}\right)$ biodeposits was obtained by difference between DW and $\mathrm{W}_{\mathrm{MM}}$. The $\mathrm{W}_{\mathrm{OM}}$ of the food ration was calculated in the same way from the mixture of microalgae. Microalgae organic matter was obtained by filtering $50 \mathrm{~mL}$ of the microalgae mixture and followed by treatment of biodeposits according to the same procedure as for organic waste.

A micro-PS quantification in faeces was realised in order to refine assimilation values. The estimation of the micro-PS share in the $\mathrm{W}_{\mathrm{OM}}$ of biodeposits was obtained during a specific experiment. The method used in this study is based on a digestion protocol of the OM 
218 with potassium hydroxide $(\mathrm{KOH}),{ }^{42}$ adapted by Dehaut et al. (2016). ${ }^{43}$ Oysters were isolated

219 at the end of the exposure (J60) in order to avoid the contamination of faeces by micro-PS

220 present in the media. Oysters were regrouped according to their treatment (18 per treatment)

221 in 5 L Pyrex crystallizing dishes filled with filtered sea water. After 12 hours, faeces were

222 taken using a plastic pipette (Deutscher) and poured into glass tubes. Biodeposits were

223 homogenized and fractionated into two equal volumes: fraction 1 (F1) and fraction 2 (F2). F1

224 was directly filtered on a GF/C filter as described previously, while F2 underwent $24 \mathrm{~h}$

225 digestion with potassium hydroxide $(10 \% \mathrm{KOH})$ at $60{ }^{\circ} \mathrm{C}$, in order to digest the $\mathrm{OM}$ and only

226 conserve the micro-PS. ${ }^{43} \mathrm{~F} 2$ was then filtered on a polycarbonate filter $(3 \mu \mathrm{m}$ of porosity, $\varnothing$

$22747 \mathrm{~mm}$, ipPORE ${ }^{\mathrm{TM}}$ Track Etched Membrane, itip ${ }^{\circledR}$ ). These filters were rinsed with acetic acid

$228(90 \%)$ to clean any residual substances resulting from saponification due to $\mathrm{KOH}$ treatment.

229 The two filters were dried, and the filter F1 was burned and then weighed in order to obtain

230 the $\mathrm{W}_{\mathrm{OM}}$ of $\mathrm{F} 1$. The filter $\mathrm{F} 2$ was analyzed under a microscope and 6 areas were selected

231 randomly and photographed to count the micro-PS. The average of the counts obtained was

232 then scaled to the entire filter surface in order to estimate the total number of micro-PS in the

233 sample and their contribution to the $\mathrm{W}_{\mathrm{OM}}$ of $\mathrm{F} 1$ for each treatment (micro-PS weight 6 and 10

$234 \mu \mathrm{m}=1.19 \times 10^{-4}$ and $5.48 \times 10^{-4} \mu \mathrm{g}$ ). This proportion of micro-PS was then subtracted in

235 proportion to the individual DW biodeposits for each treatment. After conversion of the $\mathrm{W}_{\mathrm{OM}}$

236 biodeposits and $\mathrm{W}_{\mathrm{OM}}$ microalgae to relative values, the assimilation efficiency (AE, \%) was

237 calculated by the relation (Conover, 1966): $\mathrm{AE}=\left(\% \mathrm{OM}_{\mathrm{m}}-\% \mathrm{OM}_{\mathrm{w}}\right) /\left(\left(100-\% \mathrm{OM}_{\mathrm{w}}\right) \times\right.$

$\left.238 \% \mathrm{OM}_{\mathrm{m}}\right)$, where $\mathrm{AE}$ is the assimilation efficiency, $\mathrm{OM}_{\mathrm{m}}$ is the microalgae organic matter $(0.87$

239 for Tisochrysis lutea and 0.6 for Chaetoceros gracilis) and $\mathrm{OM}_{\mathrm{w}}$ is the waste organic matter

240 (biodeposits).

241 Energy budget. Ecophysiology data were converted into energy values to define the

242 scope for growth $(\mathrm{SFG})$ for each oyster: $\mathrm{SFG}=(\mathrm{IR} \times \mathrm{AE})-\mathrm{OC}$, where $\mathrm{IR}$ is the ingestion 
rate, $\mathrm{AE}$ is the assimilation efficiency, and $\mathrm{OC}$ is the oxygen consumption. We used $20.3 \mathrm{~J}$ for $1 \mathrm{mg}$ of particulate organic matter and $14.1 \mathrm{~J}$ for $1 \mathrm{mg} \mathrm{O}{ }_{2}{ }^{44-46}$

Shell growth rate. To investigate shell growth, the shells were sawn with a 'Swap Top' Trim Saw machine (Inland, Middlesex, UK), which included a diamond Trim Saw Blade (Thin Cut) IC-40961. Shell edges were then polished for $5 \mathrm{~s}$ with various grades of water sandpaper sheets. The shell sections were examined under a Leitz Dialux 22 compound fluorescence microscope equipped with an I3-filter block and an optical micrometer. Shell growth was measured by evaluating the thickness of deposits at the ventral side of the shell, from the surface to the calcein marks, with an optical micrometer. ${ }^{47}$ Shell deposit rate (SDR) was calculated by dividing the thickness of deposits by the time which had elapsed since the marking. SDR is expressed in $\mu \mathrm{m} \cdot \mathrm{d}^{-1}$. 47,48

Measurement of the reproductive effort. After flesh dissection, the visceral mass (VM) was drained on absorbent paper, weighed and put in $10 \%$ formalin seawater for $72 \mathrm{~h}$ before being transferred into $70 \%$ ethanol. VM were cut along the sagittal plane and digital images (600 dpi) were obtained using a desktop scanner. The digital pictures were then analysed using ImageJ software (v. 1.6.0). Gonad size was characterized using a gonad development index (GDI) which is equal to the ratio of the gonad surface (G) to the VM area of a sagittal section: GDI $=\mathrm{G} / \mathrm{VM}{ }^{49,50}$

Gametogenesis analysis by histology. For histological analysis, the fixed gonads were dehydrated through a graded series of ethanol, embedded in paraffin, sectioned into $3 \mu \mathrm{m}$ slices on a rotary microtome, stained using haematoxylin and eosin and finally mounted on glass microscope slides. Gametogenesis condition was evaluated through the identification of regression signs (i.e., epithelial detachment, advanced regression stage). The presence or absence of regression signs was assessed for each individual. 
Statistical analysis. Data are presented as mean \pm standard deviation. Normality of data distribution and homogeneity of variance were tested with the Shapiro-Wilk test and the Bartlett test, respectively. Means of IR, OC, AE, SFG and GDI were compared using one-way ANOVA for each treatment $(\alpha=0.05)$. Data expressed in proportion (AE and GDI) were previously transformed by the arcsine square root function. Tukey's post hoc test was used to determine the significant differences between the averages of each group. Since the assumptions of normality and homogeneity of variance were not met for SDR data, we used the non-parametric Kruskall-Wallis test to compare means of each treatment. Fisher's exact test was used to analyse gametogenesis condition (i.e., presence or absence of regression signs). For this test, individuals at T0 were first compared to those placed under control condition (T0 vs control), in order to rule out potential laboratory or time effect on the gametogenesis condition, and be able to pool T0 and control conditions to increase the power of the statistical test. This "new control" group could thus be compared to the pooled individuals exposed to micro-PS, as to perform T0/control vs micro-PS comparison. Results were considered significant at $p<0.05$.

\section{RESULTS}

Metabolic rates: ingestion and respiration. Fluorescence measurements revealed an average ingestion rate of $20.7 \pm 5.4 \times 10^{7}$ cells $\mathrm{h}^{-1} \mathrm{~g}^{-1}$ dry weight $(\mathrm{dw})$ under control conditions; $18.7 \pm 7.7 \times 10^{7}$ cells h ${ }^{-1} \mathrm{~g}^{-1} \mathrm{dw}$ at $0.25 \mu \mathrm{g}$ micro-PS L ${ }^{-1} ; 20.9 \pm 3.2 \times 10^{7}$ cells h$^{-1}$ $\mathrm{g}^{-1} \mathrm{dw}$ at $2.5 \mu \mathrm{g} \mathrm{L}^{-1}$ and $20.3 \pm 4.5 \times 10^{7}$ cells h$^{-1} \mathrm{~g}^{-1} \mathrm{dw}$ at $25 \mu \mathrm{g} \mathrm{L}^{-1}$. The one-way ANOVA revealed no significant difference between conditions $\left(\mathrm{F}_{3,32}=0.279, p=0.840\right)$ (Figure 2a).

The average of oxygen consumption was of $1.34 \pm 0.37 \mathrm{mg} \mathrm{O}_{2} \mathrm{~h}^{-1} \mathrm{~g}^{-1} \mathrm{dw}$ under control conditions; $1.47 \pm 0.37 \mathrm{mg} \mathrm{O}_{2} \mathrm{~h}^{-1} \mathrm{~g}^{-1} \mathrm{dw}$ at $0.25 \mu \mathrm{g} \mathrm{L} \mathrm{L}^{-1} ; 1.45 \pm 0.20 \mathrm{mg} \mathrm{O}_{2} \mathrm{~h}^{-1} \mathrm{~g}^{-1} \mathrm{dw}$ at $2.5 \mu \mathrm{g}$ 
290

291

292

293

294

295

296

297

298

299

300

301

302

303

304

305

306

307

308

309

310

311

312

313

$\mathrm{L}^{-1}$ and $1.40 \pm 0.19 \mathrm{mg} \mathrm{O}_{2} \mathrm{~h}^{-1} \mathrm{~g}^{-1} \mathrm{dw}$ at $25 \mu \mathrm{g} \mathrm{\textrm {L } ^ { - 1 }}$. The one-way ANOVA revealed no significant difference between conditions $\left(\mathrm{F}_{3,32}=0.216, p=0.885\right)$ (Figure 2b).

Digestion: assimilation efficiency. The counts carried out on polycarbonate filter allowed to estimate the weight of micro-PS in the dry weight of biodeposits. This estimate amounts to approximately $2.8 \times 10^{-3} \mu \mathrm{g}$ micro-PS $\mu \mathrm{g}^{-1} \mathrm{dw}$ at $0.25 \mu \mathrm{g} \mathrm{L}{ }^{-1} ; 4.3 \times 10^{-3} \mu \mathrm{g}$ micro-PS $\mu \mathrm{g}^{-1} \mathrm{dw}$ at $2.5 \mu \mathrm{g} \mathrm{L} \mathrm{L}^{-1}$ and $28.0 \times 10^{-3} \mu \mathrm{g}$ micro-PS $\mu \mathrm{g}^{-1} \mathrm{dw}$ at $25 \mu \mathrm{g} \mathrm{L}^{-1}$. The corrected $\mathrm{OM}$ measurements obtained in oysters placed under control conditions were $73.6 \pm 7.4 \% \mathrm{OM}$ biodeposits $\left(\mathrm{OM}_{\mathrm{w}}\right)$ for $82.4 \% \mathrm{OM}$ microalgae $\left(\mathrm{OM}_{\mathrm{m}}\right)$. For oysters exposed to $0.25 ; 2.5$ and 25 $\mu \mathrm{g}$ micro-PS $\mathrm{L}^{-1}$, OM measurements were respectively $69.0 \pm 8.5 \% \mathrm{OM}_{\mathrm{w}}$ for $75.1 \% \mathrm{OM}_{\mathrm{m}}$; $79.8 \pm 3.4 \% \mathrm{OM}_{\mathrm{w}}$ for $81.9 \% \mathrm{OM}_{\mathrm{m}}$ and $78.3 \pm 6.6 \% \mathrm{OM}_{\mathrm{w}}$ for $75.9 \% \mathrm{OM}_{\mathrm{m}}$.

The assimilation data obtained from the OM data were used to obtain for each oyster an average assimilation efficiency of $48.9 \pm 18.4 \%$ for individuals placed under control conditions; $30.1 \pm 24.7 \%$ at $0.25 \mu$ micro-PS L ${ }^{-1} ; 20.4 \pm 6.7 \%$ at $2.5 \mu \mathrm{g} \mathrm{L}^{-1}$ and $3.0 \pm 13.4 \%$ at $25 \mu \mathrm{g} \mathrm{L}{ }^{-1}$. The one-way ANOVA revealed a significant difference between conditions $\left(\mathrm{F}_{3}\right.$, $\left.{ }_{13}=5.576, p=0.011\right)$. The Tukey post-hoc test revealed a significant difference between the control condition and the $25 \mu \mathrm{g} \mathrm{L}{ }^{-1}$ treatment (mean diff. 45.8\%, $p=0.009$ ) (Figure 2c).

Standardized scope for growth. Analysis of metabolic rates and assimilation efficiency indicated a mean energy balance (SFG) decreasing from the control condition to the micro-PS treatments at 0.25 and $2.5 \mu \mathrm{g} \mathrm{L}^{-1}$ (control, $88.1 \pm 23.1 \mathrm{~J} \mathrm{~h}^{-1} \mathrm{~g}^{-1} \mathrm{dw} ; 0.25 \mu \mathrm{g} \mathrm{L}^{-1}, 39.7 \pm 19.9 \mathrm{~J}$ $\left.\mathrm{h}^{-1} \mathrm{~g}^{-1} \mathrm{dw} ; 2.5 \mu \mathrm{g} \mathrm{L}{ }^{-1}, 24.8 \pm 5.6 \mathrm{~J} \mathrm{~h}^{-1} \mathrm{~g}^{-1} \mathrm{dw}\right)$ and becoming negative at $25 \mu \mathrm{g} \mathrm{L}^{-1}(-13.2 \pm 2.5$ $\left.\mathrm{J} \mathrm{h}^{-1} \mathrm{~g}^{-1} \mathrm{dw}\right)$. The one-way ANOVA revealed a significant difference between conditions $\left(\mathrm{F}_{3}\right.$, $\left.{ }_{32}=62.47, p<0.0001\right)$. The Tukey post-hoc test showed a significant difference $(p<0.0001)$ between the means of the control condition and the 3 treatments at $0.25 ; 2.5$ and $25 \mu \mathrm{g} \mathrm{L}^{-1}$. A significant difference was also observed between the mean of treatments at 0.25 and $25 \mu \mathrm{g} \mathrm{L}^{-1}$ 
314 (mean diff. $52.8 \mathrm{~J} \mathrm{~h}^{-1} \mathrm{~g}^{-1} \mathrm{dw}, p<0.0001$ ) and those of treatments at 2.5 and $25 \mu \mathrm{g} \mathrm{L} \mathrm{L}^{-1}$ (mean 315 diff. $37.9 \mathrm{~J} \mathrm{~h}^{-1} \mathrm{~g}^{-1} \mathrm{dw}, p=0.0004$ ) (Figure 3).

316 Shell growth. Shell deposition rate (SDR) measurement was obtained through calcein 317 marking in order to analyse the effect of a 2-month micro-PS exposure at different doses on 318 shell growth. The Kruskall-Wallis test showed no significant effect of micro-PS on SDR $(p=$ 319 0.252) (Figure SI.2, SI).

Reproductive effort and gametogenesis. Means of gonad development index (GDI) measured in individuals at T0 (before micro-PS exposure) and those placed under control 322 conditions were respectively of $9.2 \pm 3.2 \%$ and $7.2 \pm 7.3 \%$. For individuals treated with 0.25 ; 2.5 and $25 \mu \mathrm{g}$ micro-PS $\mathrm{L}^{-1}$, means of GDI were respectively of $7.6 \pm 8.2 \%, 8.3 \pm 5.1 \%$ and $8.0 \pm 6.4 \%$ (Figure SI.3, SI). One-way ANOVA revealed no significant differences between conditions $\left(\mathrm{F}_{4,45}=0.156, p=0.959\right)$.

Gonads observations revealed that $100 \%$ of samples were male, which can be expected for pearl oysters at this age. Histological analysis identified "normal" gametogenesis with the presence of gonadal tubules containing germ cells ranging from spermatogonia (localized in the periphery of tubules) to spermatids and spermatozoa (more central) (Figure 4a-b). Gametogenesis was also marked by a high proliferation activity in the epithelium of gonadal tubules. Small "holes" in gonadal tubules were also observed in some individuals exposed to 0.25 and $2.5 \mu \mathrm{g} \mathrm{L}^{-1}$ (Figure 4c) but not seen in the T0, control and $25 \mu \mathrm{g} \mathrm{L}^{-1}$ samples. Larger magnification analysis revealed the presence of large cells within or near to these breakthroughs (Figure 4d). These cells were composed of an eccentric nucleus (Figure 4e) and a cytoplasm that sometimes contains many granules. These cells could be assimilated to haemocytes. Epithelial detachments were also observed in gonadal tubules of individuals exposed to $25 \mu \mathrm{g} \mathrm{L}^{-1}$, with little or no proliferation activity (Figure 4f). Indeed, the remaining 
regression stages were observed in oysters for every micro-PS doses, they were especially visible at $25 \mu \mathrm{g} \mathrm{L}^{-1}$. This stage leads to haemocytes infiltrations in gonadal tubules completely or partially emptied of their germ cells whose degradation products appear in pink (Figure $4 \mathrm{~g})$.

The exact Fisher test performed on the presence or absence of regression signs revealed no significant difference between $\mathrm{T} 0$ and the control condition $(p=0.211)$. However, a significant higher proportion of pearl oysters exposed to micro-PS showed signs of regression of gametogenesis $(63 \%, p=0.0012)$ when compared to unexposed individuals (T0 and control condition, $15 \%)$.

\section{DISCUSSION}

The aim of this study was to investigate the impact of micro-PS on the physiology of $P$. margaritifera by evaluating the effects of different exposition levels micro-PS on the energy balance and reproduction. We found that there was a significant dose-dependent negative response of oysters exposed to micro-PS, with unpredictable detrimental consequences for the sustainability of pearl oyster populations, even at low concentrations of micro-PS (i.e., 0.25 $\left.\mu \mathrm{g} \mathrm{L}^{-1}\right)$

Energy budget is the amount of energy expended for an individual's maintenance (i.e., general metabolism, somatic tissue growth, and gametes production). The scope for growth (SFG) defines the surplus of energy available for growth beyond that required for maintenance, and can thus be seen as a measure of an individual's potential to thrive in its environment. The metabolic responses of a stressed organism can result in an increase in energy costs of an individual's maintenance, which, if it is not compensated by an equivalent increase in energy intake, forces the organism to sacrifice some of the energy normally allocated to functions such as growth and/or reproduction to mitigate this increase in energy 
cost. Hence, a SFG of zero would reflect a cessation of growth for an individual, while a negative SFG would indicate that the metabolic costs associated with the individual's maintenance (respiration, metabolism and reproduction) outweigh the energy absorbed by food ingestion, endangering the survival of the individual. In our study, pearl oysters ingesting plastics had a significant dose-dependent decrease in SFG, observed from doses of $0.25 \mu \mathrm{g} \mathrm{L} \mathrm{L}^{-1}$ onward. However, the shell deposit rate (i.e., actual physical growth) was not significant different among conditions after 2-months exposure, and was thus somehow maintained, despite the decrease in SFG. In addition, SFG became negative at the dose of 25 $\mu \mathrm{g} \mathrm{L}^{-1}$. These results indicate that exposed oysters had to draw their energy from reserves, or had to gain it from another biological compartment (not growth).

Ingestion rate and assimilation efficiency are considered to be the main processes responsible for energy gain in bivalves, ${ }^{51}$ and the physiological parameters that most influence SFG. ${ }^{52}$ Ingestion rate of microalgae by $P$. margaritifera was not affected by the presence of micro-PS at the tested doses. These results are in agreement with those obtained for the flat oyster Ostrea edulis, whose filtration remained unchanged after mesocosm exposure to PLA (polylactic acid) and HDPE (high density polyethylene) MP type at low (0.8 $\left.\mu \mathrm{g} \mathrm{L}^{-1}\right)$ and high $\left(80 \mu \mathrm{g} \mathrm{L}^{-1}\right)$ concentrations. ${ }^{4}$ However, these ingestion results are apparently in contradiction with those obtained in C. gigas, which showed an increase in microalgal consumption in individuals exposed to micro-PS $\left(23 \mu \mathrm{g} \mathrm{L}^{-1}\right) .{ }^{14}$ This divergence may be related to individual measurements carried out in our study and population measurements in the case of work on $C$. gigas. It is also suggested that micro-PS exposure could induce a compensatory effect on food intake in the Pacific oyster. ${ }^{14}$ In the crab C. maenas, a decrease in the energy allocated to the animal's growth has been shown after 4-weeks exposure to PP fibers (polypropylene, 1-5 mm). ${ }^{23}$ In this study, the most important factor influencing SFG was ingestion rate, which resulted in a clear decrease of $90 \% .^{23}$ 
Although ingestion rate measurements did not demonstrate any alteration due to micro-PS exposure, assimilation measurements revealed a dose-dependent decrease in AE in exposed oysters. This means that for an equal volume of water filtered by the oysters, the assimilation of microalgae was disrupted by the presence of micro-PS, and the energy provided by food intake was lower for exposed oysters. This inhibitory effect of micro-PS on food assimilation could occur either directly, through interference with the assimilation processes within the digestive system, or indirectly, through competition with microalgae present in the acclimation medium. The impact of micro-PS on assimilation efficiency has also been reported in other studies: the reduction in body weight and assimilation efficiency for the deposit-feeder Arenicola marina was correlated with a reduction in the sediment organic matter content due to the presence of plastics; ${ }^{16}$ Wright et al. (2013) found that inflammatory responses associated to MP, combined with a reduction in feeding activity and a longer residence time in the intestine, could be responsible of an energy reserves depletion in $A$. Marina $;^{17}$ also, the presence of polyamide (PA) fibers in the digestive tract of the amphipod G. fossarum was shown to inhibit assimilation efficiency. ${ }^{24}$ However, in contrast to $P$. margaritifera, an increase in absorption efficiency was observed and an enhancement of mechanical digestion was suggested in C. gigas after micro-PS exposure. ${ }^{14}$

With assimilation efficiency decreasing in correlation with micro-PS concentrations, and an ingestion rate being similar for all concentrations, the metabolic rate (indirectly measured by respiration through oxygen consumption) could have been reduced in order to compensate for the energy deficit observed with the SFG. However, our results indicate that respiration, and thus metabolic rate, were not impacted by micro-PS. Therefore, the only possibility for exposed oysters to compensate the decrease in energy balance seems to be to feed back on reproduction, by altering reproductive effort and/or gametogenesis. 
Gametogenesis in bivalves represents a particularly high energy demand period. In $P$. margaritifera, reproduction is continuous. This "opportunistic strategy" consists in investing any excess energy into the gametes production. ${ }^{53}$ The reproductive effort measured by the GDI allows for the evaluation of the amount of energy allocated specifically to reproduction. The method used in this work was previously validated in the pearl oyster and is suited to study the relationship between the trophic level and the reproductive effort. ${ }^{50}$ Our results showed that micro-PS did not influence the development of gonadal tissue, and thus had no effect on the reproductive effort of $P$. margaritifera. In all conditions, GDI measurements were particularly low in our experiment (between 7.2 and $8.3 \%$ ) compared to the data found in the literature (15 to $18 \%$ and 18 to $34 \%$ ). ${ }^{49,50}$ This difference may be explained by the age of oysters used here (i.e., 1-1.5 year old), for whom the reproductive effort is 5 times lower than individuals aged of 3 to 4 years. ${ }^{53}$ Nonetheless, despite having a similar reproductive effort, exposed oysters' gametogenesis was strongly impacted by the presence of micro-PS. Abnormal phenomena were observed with increasing concentrations of micro-PS and could be referred to as regression induced by energy deficiency. The presence of "small holes" in the gonadal tubules seems to be the premises of a regression phase. The presence of haemocytes within these breakthroughs supports this hypothesis. This could be areas where phagocytosis of germ cells is initiated. It is conceivable that these phenomena of gonadal resorption encountered in exposed oysters to micro-PS are linked to the metabolites production. These observations were made in several exposed individuals, and corroborate the bioenergy results. Indeed, a negative energy balance indicates that the animal must draw from its reserves to satisfy its metabolism and provide its maintenance, to the detriment of its growth and reproduction. In $P$. margaritifera, the excess of energy being directly intended for the gametes production, it is the gonads that also constitute the reserves (while we demonstrated that growth was not impacted). Once the gonads are exhausted, and if adverse 
437 environmental conditions persist, the animal's energy impairment is likely to become lethal.

438 These results agreed with those derived from the DEB (Dynamic Energy Budget) analysis by 439 Sussarellu et al. (2016) in C. gigas, suggesting that the energy fraction allocated to 440 reproduction seemed to shift toward structural growth and high maintenance costs following exposure to micro-PS. Transcriptome approaches have also revealed a decrease in the 442 transcripts regulation coding for proteins involved in the insulin pathway. ${ }^{14}$ Hence, micro-PS 443 exposure may affect gene regulation in response to insulin signalling which is responsible for 444 germ cell proliferation, differentiation and maturation. ${ }^{54}$ This hypothesis would explain the 445 interruption of germ cell proliferation in the gonadal tubules of exposed pearl oysters which result in epithelial detachments. This phenomenon was also reported in the pearl oyster 447 conditioned in a medium weakly enriched in microalgae $\left(1.5\right.$ cells $\left.\mu \mathrm{L}^{-1}\right){ }^{50}$ That provide a second explanation to the divergence in food behaviour between $C$. gigas and $P$. margaritifera which could be related to the energetic support to gametogenesis, partly based on glycogen reserves in C. gigas $^{55}$ and completely dependent on food for P. margaritifera; the gonadic tissue serving as energy buffer explaining resorption figures observed in histology. In any case, these results provide further knowledge about the impact of MP on marine bivalves. At a different reproduction level, the impact of micro-PS on the gametogenesis of $P$. margaritifera complements results on gametes quality/quantity and larval development in C. gigas, ${ }^{14}$ with upstream new data.

456 Note that virgin micro-PS used in this study contain a slight anionic charge from sulfate 457 ester and are cross-linked with divinylbenzene (DVB). These non-functionalized microbeads 458 are packaged in an aqueous suspension with minimal surfactant in the final preparation. Thus, we cannot distinguish between the possible mechanisms explaining the toxicity of micro-PS, to which direct particle toxicity and effects of micro-PS associated-chemicals such as DVB, 
461

462

463

464

465

466

467

468

469

470

471

472

473

474

475

476

477

478

479

480

481

482

may contribute. Although we cannot establish an impact of these chemicals in our experiment, background effects should be consider. ${ }^{56}$

In conclusion, this study highlights the impact of ingesting a diet containing polystyrene microbeads on the assimilation efficiency of the pearl oyster which directly influences its energy balance. The dose-dependent decrease in AE and SFG supports these results and demonstrates an immutable effect of micro-PS on the oyster physiology. Given the bioenergy results and the strategy reserves management of $P$. margaritifera, the decrease in energy gain,

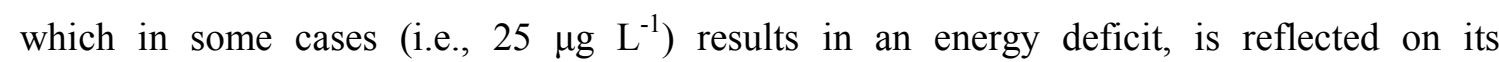
reproduction. Gonads appear to provide the missing energy to maintain animals' metabolism through the production of metabolites derived from germ cells phagocytosis. The pearl oyster exposed to micro-PS during a 2-month period thus maintains its metabolism and its vital functions at the expense of its reproduction, and thus of its future population sustainability. Taken together, our study and future work on the topic should promote decision-making on plastic waste management measures in Polynesian lagoons, especially in atolls that have 30 to 40 years of pearl farming history without waste regulations nor clean up. Our work aims to provide information to local authorities in order to regulate the flow of pearl farm equipments in direction to pearl farming atolls and implement a waste management policy such as collection and recycling of these equipments.

\section{ASSOCIATED CONTENT}

\section{* Supporting information}

The Supporting Information is available free of charge on the ACS Publications website at DOI: 
The SI contains supplementary figures about the polymer type confirmation of micro-PS 6

484

485

486

487

488

489

490

491

492

493

494

495

496

497

498

499

500

501

502

503 and $10 \mu \mathrm{m}$ by Raman micro-spectroscopy analysis; the effect of micro-PS on the SDR and the GDI of P. margaritifera. Figure SI.1, SI.2 and SI.3 (PDF)

\section{AUTHOR INFORMATION}

\section{Corresponding Author}

* Phone: +689 405460 47; fax: +689 405460 99; e-mails: tony.gardon@ifremer.fr and gilles.le.moullac@ifremer.fr

\section{Present Address}

Ifremer, UMR Ecosystèmes Insulaires Océaniens (EIO), UMR 241 UPF/ILM/IRD/Ifremer, Centre du Pacifique, BP 49, 98719, Taravao, French Polynesia.

\section{ORCID}

Tony Gardon: 0000-0002-5761-0526

Gilles Le Moullac: 0000-0003-3749-8239

\section{Notes}

The authors declare no competing financial interest.

\section{ACKNOLEDGMENTS}

We would like to thank all the RMPF technicians and personnel who helped during the experimental stages of this work. Our thanks extend to Arnaud Huvet (Ifremer Centre de Brest, LPI, UMR LEMAR) and Ika Paul-Pont (CNRS, Université de Bretagne Occidentale, UMR LEMAR) for fruitful discussions. This study was a part of the MerLIN microplastics project, funded by Ifremer. Tony Gardon was funded by a grant of the Labex Corail. 
504

505

506

507

508

509

510

511

512

513

514

515

516

517

518

519

520

521

522

523

524

525

526

527

\section{REFERENCES}

(1) PlasticsEurope. Plastics - the Facts 2016: An analysis of European Plastics Production, Demand and Waste Data (14.02.17); PlasticsEurope: Brussels, Belgium, 2017; http://www.plasticseurope.org/.

(2) Jambeck, J. R.; Geyer, R.; Wilcox, C.; Siegler, T. R.; Perryman, M.; Andrady, A.; Narayan, R.; Law, K. L. Plastic Waste Inputs from Land into the Ocean. Science 2015, 347 (6223), 768-771.

(3) Barnes, D. K. A.; Galgani, F.; Thompson, R. C.; Barlaz, M. Accumulation and Fragmentation of Plastic Debris in Global Environments. Philos. Trans. R. Soc. Lond. B Biol. Sci. 2009, 364 (1526), 1985-1998.

(4) Arthur, C.; Baker, J.; Bamford, H. Proceedings of the International Research Workshop on the Occurrence, Effects, and Fate of Microplastic Marine Debris. NOAA Technical Memorandum NOS-OR\&R-30 2009.

(5) Andrady, A. L. Microplastics in the Marine Environment. Mar. Pollut. Bull. 2011, 62 (8), 1596-1605.

(6) Derraik, J. G. B. The Pollution of the Marine Environment by Plastic Debris: A Review. Mar. Pollut. Bull. 2002, 44 (9), 842-852.

(7) Thompson, R. C.; Olsen, Y.; Mitchell, R. P.; Davis, A.; Rowland, S. J.; John, A. W. G.; McGonigle, D.; Russell, A. E. Lost at Sea: Where Is All the Plastic? Science 2004, 304 (5672), 838-838.

(8) Ng, K. L.; Obbard, J. P. Prevalence of Microplastics in Singapore's Coastal Marine Environment. Mar. Pollut. Bull. 2006, 52 (7), 761-767.

(9) Fendall, L. S.; Sewell, M. A. Contributing to Marine Pollution by Washing Your Face: Microplastics in Facial Cleansers. Mar. Pollut. Bull. 2009, 58 (8), 1225-1228. 
(10) Rochman, C. M.; Browne, M. A.; Underwood, A. J.; van Franeker, J. A.; Thompson, R. C.; Amaral-Zettler, L. A. The Ecological Impacts of Marine Debris: Unraveling the Demonstrated Evidence from What Is Perceived. Ecology 2016, 97 (2), 302-312.

(11) Browne, M. A.; Dissanayake, A.; Galloway, T. S.; Lowe, D. M.; Thompson, R. C. Ingested Microscopic Plastic Translocates to the Circulatory System of the Mussel, Mytilus edulis (L.). Environ. Sci. Technol. 2008, 42 (13), 5026-5031.

(12) Van Cauwenberghe, L.; Janssen, C. R. Microplastics in Bivalves Cultured for Human Consumption. Environ. Pollut. 2014, 193, 65-70.

(13) Avio, C. G.; Gorbi, S.; Milan, M.; Benedetti, M.; Fattorini, D.; d’Errico, G.; Pauletto, M.; Bargelloni, L.; Regoli, F. Pollutants Bioavailability and Toxicological Risk from Microplastics to Marine Mussels. Environ. Pollut. 2015, 198, 211-222.

(14) Sussarellu, R.; Suquet, M.; Thomas, Y.; Lambert, C.; Fabioux, C.; Pernet, M. E. J.; Le Goïc, N.; Quillien, V.; Mingant, C.; Epelboin, Y.; et al. Oyster Reproduction Is Affected by Exposure to Polystyrene Microplastics. Proc. Natl. Acad. Sci. 2016, 113 (9), 2430-2435.

(15) Graham, E. R.; Thompson, J. T. Deposit- and Suspension-Feeding Sea Cucumbers (Echinodermata) Ingest Plastic Fragments. J. Exp. Mar. Biol. Ecol. 2009, 368 (1), 2229.

(16) Besseling, E.; Wegner, A.; Foekema, E. M.; van den Heuvel-Greve, M. J.; Koelmans, A. A. Effects of Microplastic on Fitness and PCB Bioaccumulation by the Lugworm Arenicola marina (L.). Environ. Sci. Technol. 2013, 47 (1), 593-600.

(17) Wright, S. L.; Rowe, D.; Thompson, R. C.; Galloway, T. S. Microplastic Ingestion Decreases Energy Reserves in Marine Worms. Curr. Biol. CB 2013, 23 (23), R10311033. 
552

553

554

555

556

557

558

559

560

561

562

563

564

565

566

567

568

569

570

571

572

573

574

575

(18) Cole, M.; Lindeque, P.; Fileman, E.; Halsband, C.; Goodhead, R.; Moger, J.; Galloway, T. S. Microplastic Ingestion by Zooplankton. Environ. Sci. Technol. 2013, 47 (12), $6646-6655$.

(19) Cole, M.; Lindeque, P.; Fileman, E.; Halsband, C.; Galloway, T. S. The Impact of Polystyrene Microplastics on Feeding, Function and Fecundity in the Marine Copepod Calanus helgolandicus. Environ. Sci. Technol. 2015, 49 (2), 1130-1137.

(20) Lee, K.-W.; Shim, W. J.; Kwon, O. Y.; Kang, J.-H. Size-Dependent Effects of Micro Polystyrene Particles in the Marine Copepod Tigriopus japonicus. Environ. Sci. Technol. 2013, 47 (19), 11278-11283.

(21) Jeong, C.-B.; Won, E.-J.; Kang, H.-M.; Lee, M.-C.; Hwang, D.-S.; Hwang, U.-K.; Zhou, B.; Souissi, S.; Lee, S.-J.; Lee, J.-S. Microplastic Size-Dependent Toxicity, Oxidative Stress Induction, and p-JNK and p-P38 Activation in the Monogonont Rotifer (Brachionus koreanus). Environ. Sci. Technol. 2016, 50 (16), 8849-8857.

(22) Murray, F.; Cowie, P. R. Plastic Contamination in the Decapod Crustacean Nephrops norvegicus (Linnaeus, 1758). Mar. Pollut. Bull. 2011, 62 (6), 1207-1217.

(23) Watts, A. J. R.; Urbina, M. A.; Corr, S.; Lewis, C.; Galloway, T. S. Ingestion of Plastic Microfibers by the Crab Carcinus maenas and Its Effect on Food Consumption and Energy Balance. Environ. Sci. Technol. 2015, 49 (24), 14597-14604.

(24) Blarer, P.; Burkhardt-Holm, P. Microplastics Affect Assimilation Efficiency in the Freshwater Amphipod Gammarus fossarum. Environ. Sci. Pollut. Res. 2016, 23 (23), $23522-23532$.

(25) Rist, S. E.; Assidqi, K.; Zamani, N. P.; Appel, D.; Perschke, M.; Huhn, M.; Lenz, M. Suspended Micro-Sized PVC Particles Impair the Performance and Decrease Survival in the Asian Green Mussel Perna viridis. Mar. Pollut. Bull. 2016, 111 (1-2), 213-220. 
(26) Besseling, E.; Wang, B.; Lürling, M.; Koelmans, A. A. Nanoplastic Affects Growth of S. obliquus and Reproduction of D. magna. Environ. Sci. Technol. 2014, 48 (20), $12336-12343$.

(27) Wright, S. L.; Thompson, R. C.; Galloway, T. S. The Physical Impacts of Microplastics on Marine Organisms: A Review. Environ. Pollut. 2013, 178, 483-492.

(28) Rochman, C. M.; Hoh, E.; Kurobe, T.; Teh, S. J. Ingested Plastic Transfers Hazardous Chemicals to Fish and Induces Hepatic Stress. Sci. Rep. 2013, 3 (1), 3263.

(29) Bakir, A.; Rowland, S. J.; Thompson, R. C. Enhanced Desorption of Persistent Organic Pollutants from Microplastics under Simulated Physiological Conditions. Environ. Pollut. 2014, 185, 16-23.

(30) Paul-Pont, I.; Lacroix, C.; González Fernández, C.; Hégaret, H.; Lambert, C.; Le Goïc, N.; Frère, L.; Cassone, A.-L.; Sussarellu, R.; Fabioux, C.; et al. Exposure of Marine Mussels Mytilus spp. to Polystyrene Microplastics: Toxicity and Influence on Fluoranthene Bioaccumulation. Environ. Pollut. 2016, 216, 724-737.

(31) Collignon, A.; Hecq, J.-H.; Galgani, F.; Voisin, P.; Collard, F.; Goffart, A. Neustonic Microplastic and Zooplankton in the North Western Mediterranean Sea. Mar. Pollut. Bull. 2012, 64 (4), 861-864.

(32) Huvet, A.; Paul-Pont, I.; Fabioux, C.; Lambert, C.; Suquet, M.; Thomas, Y.; Robbens, J.; Soudant, P.; Sussarellu, R. Reply to Lenz et Al.: Quantifying the Smallest Microplastics Is the Challenge for a Comprehensive View of Their Environmental Impacts. Proc. Natl. Acad. Sci. U. S. A. 2016, 113 (29), E4123-4124.

(33) Barbier, E. B.; Hacker, S. D.; Kennedy, C.; Koch, E. W.; Stier, A. C.; Silliman, B. R. The Value of Estuarine and Coastal Ecosystem Services. Ecol. Monogr. 2011, 81 (2), $169-193$. 
(34) Pouvreau, S.; Jonquières, G.; Buestel, D. Filtration by the Pearl Oyster, Pinctada margaritifera, under Conditions of Low Seston Load and Small Particle Size in a Tropical Lagoon Habitat. Aquaculture 1999, 176 (3-4), 295-314.

(35) Cole, M.; Lindeque, P. K.; Fileman, E.; Clark, J.; Lewis, C.; Halsband, C.; Galloway, T. S. Microplastics Alter the Properties and Sinking Rates of Zooplankton Faecal Pellets. Environ. Sci. Technol. 2016, 50 (6), 3239-3246.

(36) Green, D. S. Effects of Microplastics on European Flat Oysters, Ostrea edulis and Their Associated Benthic Communities. Environ. Pollut. 2016, 216, 95-103.

(37) Andréfouët, S.; Thomas, Y.; Lo, C. Amount and Type of Derelict Gear from the Declining Black Pearl Oyster Aquaculture in Ahe Atoll Lagoon, French Polynesia. Mar. Pollut. Bull. 2014, 83 (1), 224-230.

(38) Eriksen, M.; Maximenko, N.; Thiel, M.; Cummins, A.; Lattin, G.; Wilson, S.; Hafner, J.; Zellers, A.; Rifman, S. Plastic Pollution in the South Pacific Subtropical Gyre. Mar. Pollut. Bull. 2013, 68 (1), 71-76.

(39) Connors, E. J. Distribution and Biological Implications of Plastic Pollution on the Fringing Reef of Mo'orea, French Polynesia. PeerJ 2017, 5, e3733.

(40) Chávez-Villalba, J.; Soyez, C.; Aurentz, H.; Le Moullac, G. Physiological Responses of Female and Male Black-Lip Pearl Oysters (Pinctada margaritifera) to Different Temperatures and Concentrations of Food. Aquat. Living Resour. 2013, 26 (3), 263271.

(41) Savina, M.; Pouvreau, S. A Comparative Ecophysiological Study of Two Infaunal Filter-Feeding Bivalves: Paphia rhomboïdes and Glycymeris glycymeris. Aquaculture 2004, 239 (1-4), 289-306. 
623

624

625

626

627

628

629

630

631

632

633

634

635

636

637

638

639

640

641

642

643

644

645

646

(42) Foekema, E. M.; De Gruijter, C.; Mergia, M. T.; van Franeker, J. A.; Murk, A. J.; Koelmans, A. A. Plastic in North Sea Fish. Environ. Sci. Technol. 2013, 47 (15), 88188824.

(43) Dehaut, A.; Cassone, A.-L.; Frère, L.; Hermabessiere, L.; Himber, C.; Rinnert, E.; Rivière, G.; Lambert, C.; Soudant, P.; Huvet, A.; et al. Microplastics in Seafood: Benchmark Protocol for Their Extraction and Characterization. Environ. Pollut. 2016, $215,223-233$.

(44) Bayne, B. L.; Hawkins, A. J. S.; Navarro, E. Feeding and Digestion by the Mussel Mytilus edulis L. (Bivalvia: Mollusca) in Mixtures of Silt and Algal Cells at Low Concentrations. J. Exp. Mar. Biol. Ecol. 1987, 111 (1), 1-22.

(45) Gnaiger, E. Heat Dissipation and Energetic Efficiency in Animal Anoxibiosis: Economy Contra Power. J. Exp. Zool. 1983, 228 (3), 471-490.

(46) Bayne, B. L.; Newell, R. C. Physiological Energetics of Marine Molluscs; 1983; Vol. 4, pp 407-515.

(47) Linard, C.; Gueguen, Y.; Moriceau, J.; Soyez, C.; Hui, B.; Raoux, A.; Cuif, J. P.; Cochard, J.-C.; Le Pennec, M.; Le Moullac, G. Calcein Staining of Calcified Structures in Pearl Oyster Pinctada margaritifera and the Effect of Food Resource Level on Shell Growth. Aquaculture 2011, 313 (1), 149-155.

(48) Joubert, C.; Linard, C.; Le Moullac, G.; Soyez, C.; Saulnier, D.; Teaniniuraitemoana, V.; Ky, C. L.; Gueguen, Y. Temperature and Food Influence Shell Growth and Mantle Gene Expression of Shell Matrix Proteins in the Pearl Oyster Pinctada margaritifera. PloS One 2014, 9 (8), e103944.

(49) Fournier, J.; Levesque, E.; Pouvreau, S.; Le Pennec, M.; Le Moullac, G. Influence of Plankton Concentration on Gametogenesis and Spawning of the Black Lip Pearl Oyster 
Pinctada margaritifera in Ahe Atoll Lagoon (Tuamotu Archipelago, French Polynesia). Mar. Pollut. Bull. 2012, 65 (10-12), 463-470.

(50) Le Moullac, G.; Soyez, C.; Sham-Koua, M.; Levy, P.; Moriceau, J.; Vonau, V.; Maihota, M.; Cochard, J. C. Feeding the Pearl Oyster Pinctada margaritifera during Reproductive Conditioning. Aquac. Res. 2013, 44 (3), 404-411.

(51) Hawkins, A. J. S.; James, M. R.; Hickman, R. W.; Hatton, S.; Weatherhead, M. Modelling of Suspension-Feeding and Growth in the Green-Lipped Mussel Perna canaliculus Exposed to Natural and Experimental Variations of Seston Availability in the Marlborough Sounds, New Zealand. Mar. Ecol. Prog. Ser. 1999, 191, 217-232.

(52) Albentosa, M.; Viñas, L.; Besada, V.; Franco, A.; González-Quijano, A. First Measurements of the Scope for Growth (SFG) in Mussels from a Large Scale Survey in the North-Atlantic Spanish Coast. Sci. Total Environ. 2012, 435-436, 430-445.

(53) Pouvreau, S.; Gangnery, A.; Tiapari, J.; Lagarde, F.; Garnier, M.; Bodoy, A. Gametogenic Cycle and Reproductive Effort of the Tropical Blacklip Pearl Oyster, Pinctada margaritifera (Bivalvia: Pteriidae), Cultivated in Takapoto Atoll (French Polynesia). Aquat. Living Resour. 2000, 13 (1), 37-48.

(54) Gricourt, L.; Mathieu, M.; Kellner, K. An Insulin-like System Involved in the Control of Pacific Oyster Crassostrea gigas Reproduction: HrIGF-1 Effect on Germinal Cell Proliferation and Maturation Associated with Expression of an Homologous Insulin Receptor-Related Receptor. Aquaculture 2006, 251 (1), 85-98.

(55) Jouaux, A.; Blin, J. L.; Adeline, B.; Heude-Berthelin, C.; Sourdaine, P.; Mathieu, M.; Kellner, K. Impact of Energy Storage Strategies on Gametogenesis and Reproductive Effort in Diploid and Triploid Pacific Oysters Crassostrea gigas - Involvement of Insulin Signaling. Aquaculture 2013, 388-391 (Supplement C), 173-181. 
671 (56) Karami, A. Gaps in Aquatic Toxicological Studies of Microplastics. Chemosphere 672 2017, 184, 841-848.

673 


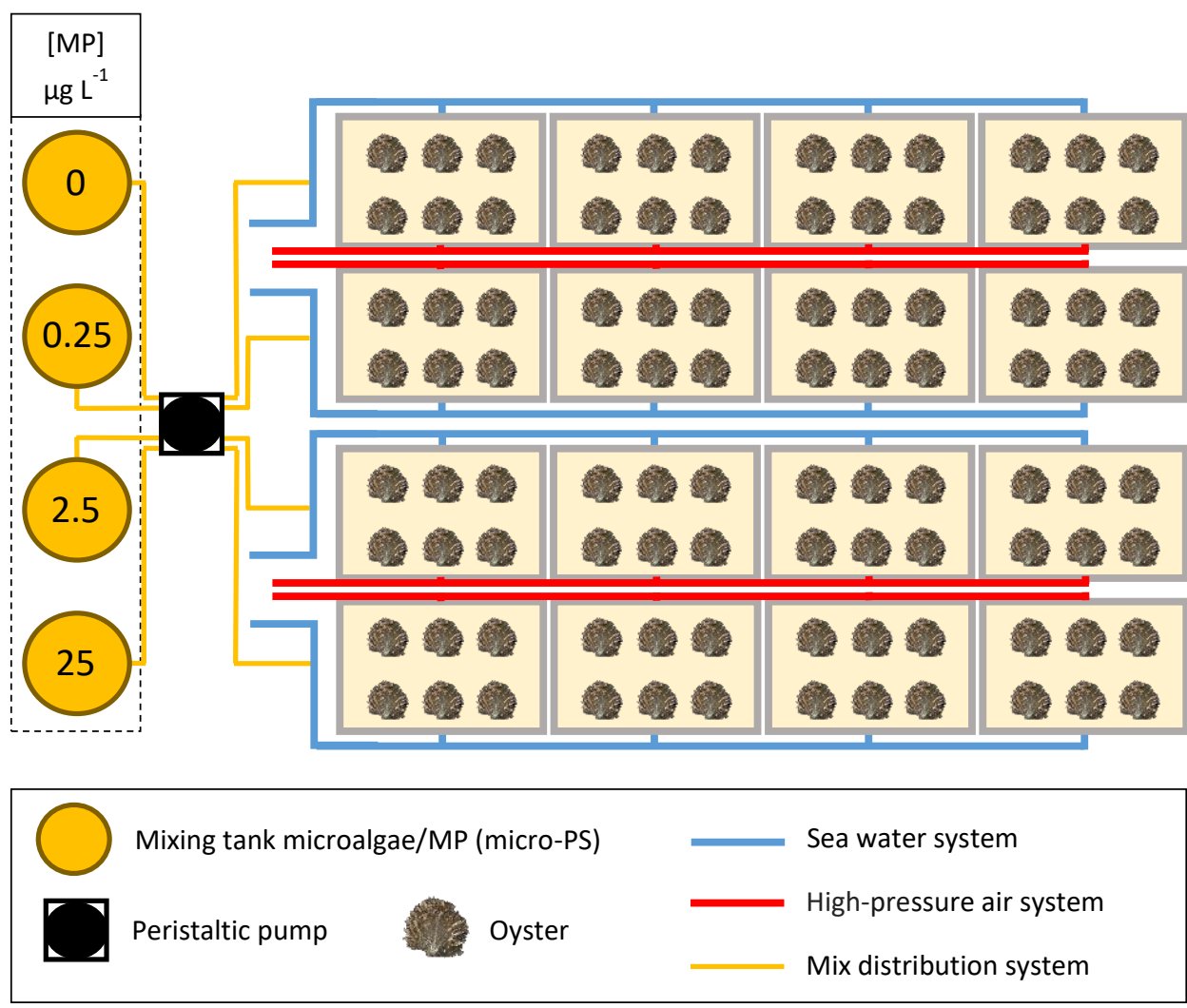

Figure 1. Experimental exposure device of oysters to microplastics. 


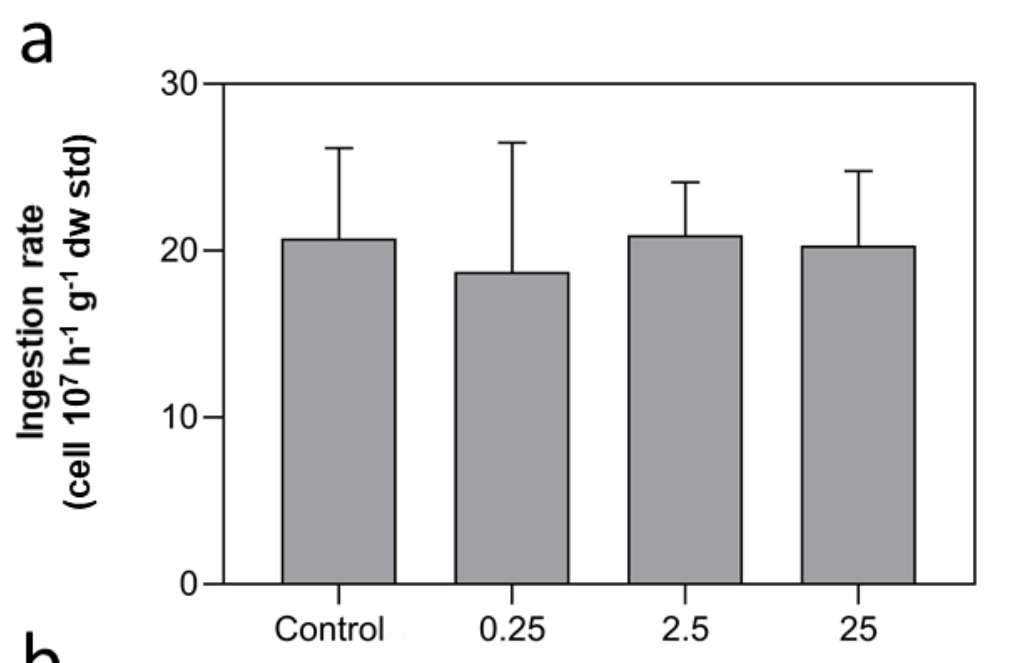

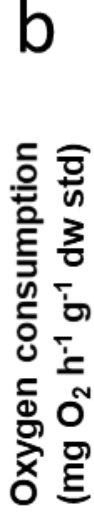

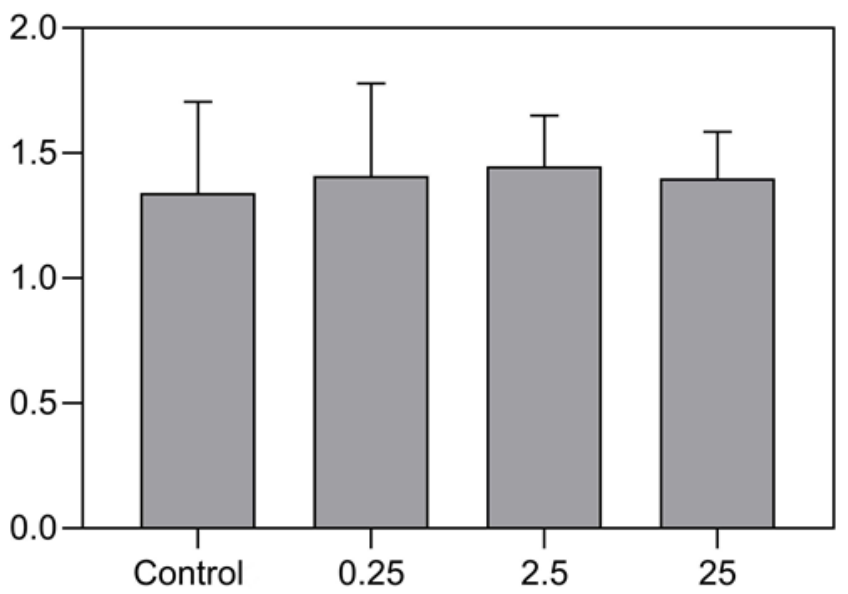

C

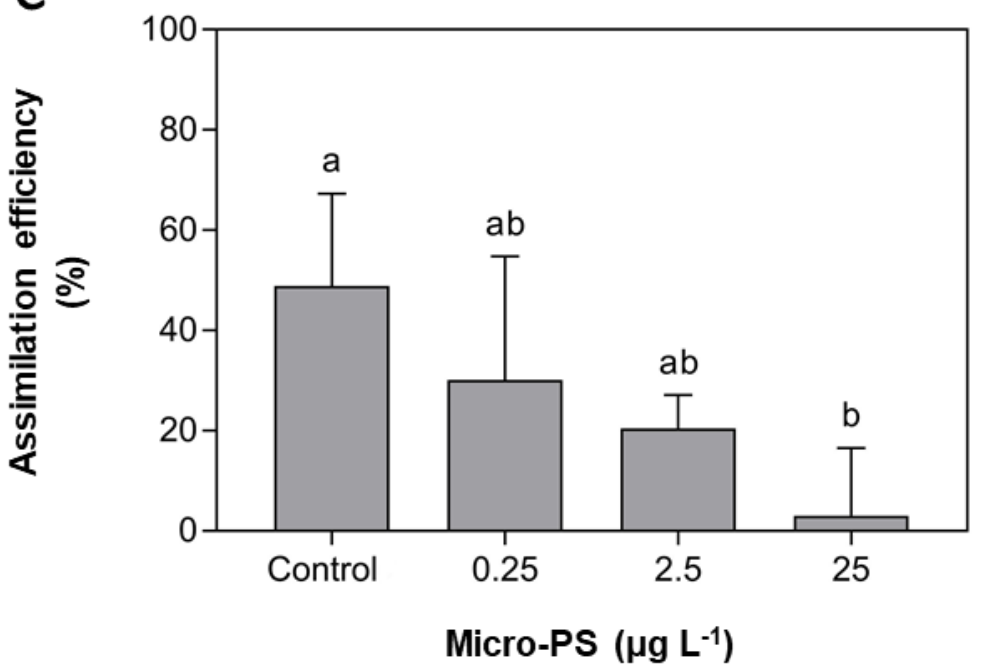

Figure 2. Effect of microplastics on bioenergetic parameters of $P$. margaritifera. Impact of micro-PS on: ingestion rate (a), oxygen consumption (b) and assimilation efficiency (c). Mean \pm standard deviation $(8 \leq \mathrm{n} \leq 12)$. 


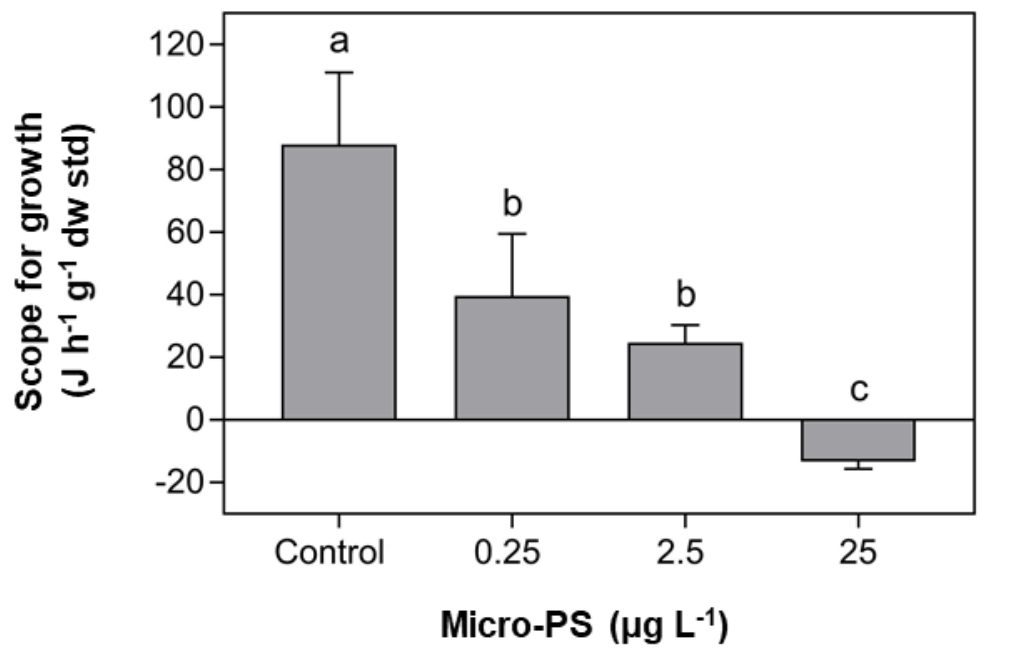

Figure 3. Energy balance of oysters exposed to micro-PS. Mean \pm standard deviation $(8 \leq \mathrm{n} \leq 12)$. 

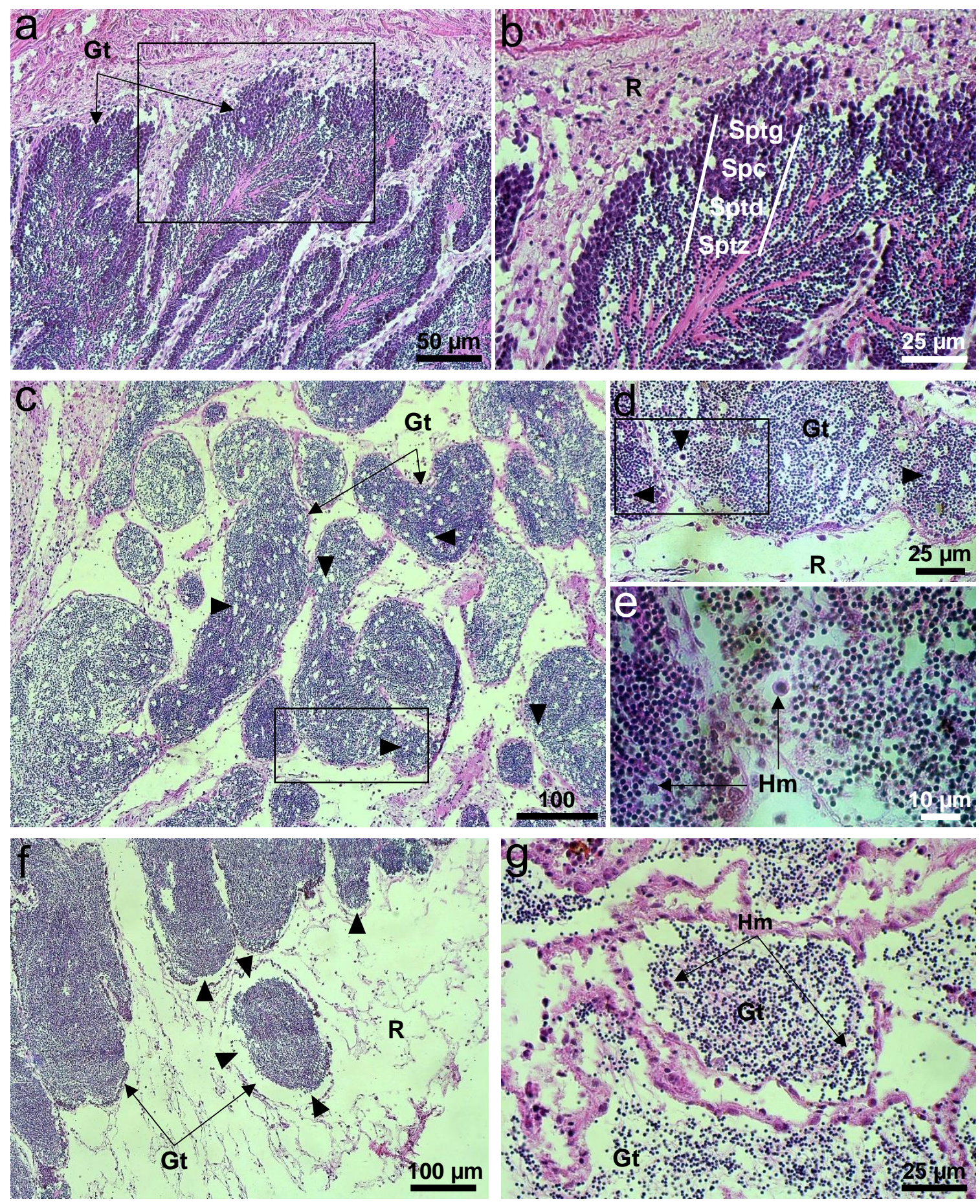

Figure 4. Histology panels from the gonads analysis of oysters exposed to micro-PS. (a, b): intermediate stage gametogenesis in a control sample; (c, d, e): gametogenesis at an intermediate stage in a sample exposed to $2.5 \mu \mathrm{g} \mathrm{L}^{-1}$; (f): gametogenesis at an intermediate stage in a sample exposed to $25 \mu \mathrm{g} \mathrm{L}^{-1}$; $(\mathrm{g})$ : regression of gametogenesis in a sample exposed to $25 \mu \mathrm{g} \mathrm{L} \mathrm{L}^{-1}$. Hm: haemocytes; Sptg: spermatogonia; Sptc: spermatocytes; Sptd: spermatids; Sptz: spermatozoa; Gt: gonadal tubules; R: reserve tissues. Arrowhead: regression areas. (b) and (d) are expanded images from (a) and (c), respectively, and (e) is expanded image from $(d)$. 